\title{
VARIATION IN PHENOLICS, FLAVONOIDS AT DIFFERENT STAGES OF FRUIT DEVELOPMENT OF POUTERIA CAMPECHIANA (KUNTH) BAEHNI AND ITS ANTIOXIDANT ACTIVITY
}

\author{
A. V. SUNILA ${ }^{1}$, K. MURUGAN2* \\ ${ }^{1}$ Department of Botany, Bharathiar University, Coimbatore, Tamil Nadu 641046, ${ }^{2}$ Department of Botany, University College, Trivandrum, \\ Kerala, India \\ Email: harimurukan@gmail.com \\ Received: 08 Jun 2017 Revised and Accepted: 21 Sep 2017
}

\begin{abstract}
Objective: The work was aimed to study the changes in the level of phenols and flavonoids during fruit development and its antioxidant potential. The number of experiments conducted was twenty for each case. Polyphenols at different ontological stages may help producers and food
\end{abstract} technologists to identify which cultivar and/or maturity stage are most adequate for their need.

Methods: Egg fruits were harvested and classified into six developmental stages based on week after pollination (WAP): stage I (4WAP); stage II (8 WAP); stage III (12WAP); stage IV (16WAP); stage V (20 WAP) and stage VI (24 WAP). The total phenolics and flavonoids of egg fruits at different developmental stages were investigated. The antioxidant capacities of ethanolic and aqueous extracts were determined by different assays such as FRAP, DPPH, ABTS, superoxide anion, hydroxyl radical and $\mathrm{H}_{2} \mathrm{O}_{2}$ scavenging assays.

Results: The total phenolic contents varied from 30.35 to $2.26 \mathrm{mg}$ chlorogenic acid equivalents/g dry weight (DW), and the total flavonoid contents ranged from 0.683 to $3.37 \mathrm{mg}$ rutin equivalents/g DW. Total phenolics showed an initial increase and subsequently decreased during development. In contrast, flavonoids increased from stage I to VI. Antioxidant assays showed varied patterns of inhibition.

Conclusion: Significant correlations were observed between antioxidant capacities and total phenolic and flavonoid contents.

Keywords: Egg fruits, Phenolic, Flavonoid, Antioxidant, Development

(C) 2017 The Authors. Published by Innovare Academic Sciences Pvt Ltd. This is an open access article under the CC BY license (http://creativecommons.org/licenses/by/4.0/) DOI: http://dx.doi.org/10.22159/ijpps.2017v9i11.20588

\section{INTRODUCTION}

Studies have indicated that phenolic compounds are a major source of natural antioxidants in foods of plant origin which in turn exhibit a wide spectrum of biochemical activities such as antimicrobial, antimutagenic, anticarcinogenic as well as the ability to modify the gene expression [1]. Numerous epidemiological studies cfinm significant relationship between the high dietary intake of flavonoids and the reduction of cardiovascular as well as carcinogenic risks. Various factors (climatic, agronomic, genomic, pre-and post-harvest conditions and processing) may affect the chemical composition of plant foods and may have a significant role in determining the phenolic composition and the bioactivity of these compounds [2]. The ripening stage is another important factor that may influence the composi tional quality of fruits and vegetables. Indeed, natural antioxidants warrant further scientific scrutiny, given their activity against free radicals, which contribute to chronic degenerative diseases. Medicinal plants play important roles in preventing various diseases, and have received much attention from many researchers over the last few decades. Studies on the antioxidant contents of fruits and vegetables are increasing because natural antioxidant consumption has been found to be related with decreased risk for cancer and heart diseases. Harvest time is essential to get a high quality fruit with storage potential. Some physiological properties can be affected by cultivar; agronomic conditions and maturity stage. Polyphenolics are present in vegetables and fruits functionally proven as antioxidants, anticarcinogenic, antimicrobial, antiallergic and also have antimutagenic and anti-inflammatory properties [3]. The anthocyanins, flavonoids and some non-flavonoids are also responsible of antioxidant properties [4]. Many of the modern diseases are caused by the oxidative stress which is the result of imbalance between formation and neutralization of reactive free radicals. These free radicals are continuously produced and neutralized in the body so as to maintain the constant redox state. These reactive free radicals are generated either by-products of respiration (in reducing molecular oxygen) or exogenous sources like stress, UV radiation, rich polyunsaturated fatty acid diet, trace metals in dietor absence of exercise [5]. Reactive free radicals include reactive oxygen species (ROS) like superoxide anion radical $\left(\mathrm{O}_{2}^{-}\right)$, hydroxyl free radical $(\mathrm{OH})$, peroxyl radical (ROO) or reactive nitrogen species (RNS). The ROS or RNS cause oxidative damage of biological macromolecules which plays role in the pathogenesis of diverse degenerative disorders like diabetes, Alzheimer's, Parkinson's, cardiovascular diseases including programmed cell death i.e. aging [6]. All human cells can protect themselves through the antioxidant defense systems. The aim of this study was to investigate the level of potential antioxidant compounds and there in vitro antioxidant potentials of the aqueous and ethanolic fruit extracts from Pouteria campechiana. To the best of our knowledge, no scientific studies have been conducted so far related to the complete phytochemical profile of this fruit and hence the study was attempted. This is an underutilized fruit and no drugs have been reported.

\section{MATERIALS AND METHODS}

\section{Chemicals and reagents}

NBT (Merck, India), 2-deoxyribose (Merck, India), tripyridyltriazine (Molbase, India), ABTS (Merck, India), EDTA solution (Merck, India), NADH (SRL, India), DPPH (Ottokemi, India), Ferric chloride (Alliance Global, India), Hydrogen peroxide (Arihant chemicals, India) Folin Ciocalteu's reagent (Merck, India), Aluminium chloride (Merck India) Potassium acetate (Merck India).

\section{Plant material}

Egg fruits at different stages (4WAP [early], 8WAP [young], 12WAP [green mature], 16WAP [green unripened], 20WAP [yellow unripened] and 24WAP [fully ripened]) were freshly collected from Palode region $\left(8^{\circ} 30^{\prime} 0^{\prime \prime} \mathrm{N}, 76^{\circ} 55^{\prime} 12^{\prime \prime} \mathrm{E}\right)$ for estimating total phenol content and flavonoids. Fruits of fully ripened stage were also collected for analyzing the antioxidant capacity of the fruits Voucher specimen (UCBD 13701) was deposited in the herbarium of the department of Botany, University College, Thiruvananthapuram. 
Fully ripened fruits were thoroughly washed and wiped with clean tissue paper to avoid dust on the fruit surface. Then the fruits were cut into pieces and washed with water for further analysis.

\section{Isolation and assay of phenols and antioxidants}

Isolation of polyphenols was done with $70 \%$ methanol with slight modifications using Folin-Ciocalteu reagent [7]. Absorbancy was noted at $650 \mathrm{~nm}$. Total flavonoids were determined by standard methodology using potassium acetate and aluminium chloride solution as reagents [8]. The absorbancy was noted at $510 \mathrm{~nm}$.

\section{Antioxidant assays}

Superoxide radical scavenging capacity of aqueous as well as ethanolic extract of fully ripened fruit was assessed [9]. Reaction mixture contained $1 \mathrm{ml}$ of NBT, $1 \mathrm{ml} \mathrm{NADH}, 0.1 \mathrm{ml}$ ascorbic acid and fruit samples at different concentrations. Hydroxyl ion scavenging assay was carried out in both extracts using 2-deoxyribose, ferrous sulphate, and $\mathrm{H}_{2} \mathrm{O}_{2}$ solution [10]. DPPH scavenging assay in aqueous

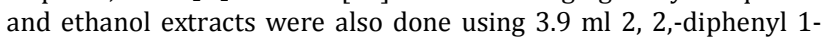
picrylhydrozyl in sample at different dilutions [11].

FRAP assay of the fruit was also conducted and the reagent contained $0.1 \mathrm{M}$ phosphate buffer at $\mathrm{pH} 3.6,10 \mathrm{mmol}$ tripyridyltriazine solution, in $40 \mathrm{mmol} \mathrm{Hcl}$, and $20 \mathrm{mmol} \mathrm{Ferric}$ chloride [12]. Hydrogen peroxide scavenging assay of fully ripened fruit in water and ethanolic extracts were assessed using $\mathrm{H}_{2} \mathrm{O}_{2}$ as reagent [13]. ABTS scavenging assay of fruits in both extract were measured as described by $\mathrm{Re}$ et al. [14]. The ABTS radical cation solution was pre generated by adding $7 \mathrm{mmol}$ ABTS and $2.45 \mathrm{mmol}$ potassium persuphate and incubated for $16 \mathrm{~h}$ in the darkness at room temperature.

The metal chelating activity of the two extracts was determined and reagent contains ferric chloride, ferrozine and sodium EDTA solution [15].

\section{Statistical analysis}

Experiments were carried out in 20 replicates. Data were presented as means \pm standard deviation. Two way analysis of variance (ANOVA) was performed using The Origin 8.5 (Origin Lab Corporation, Northampton, USA) software to analyze the statistical significance. The $p<0.05$ considered as significant.

\section{RESULTS AND DISCUSSION}

\section{Total phenolics and flavonoids}

The freshly-harvested egg fruits were classified into six groups according to their botanical characteristics: I (4WAP); stage II (8 WAP); stage III (12WAP); stage IV (16WAP); stage V (20 WAP) and stage VI (24 WAP) in table (1).

Table 1: Physical parameters for the identification of different stages of egg fruit

\begin{tabular}{|c|c|c|c|c|c|c|}
\hline parameters & $\begin{array}{l}\text { Stage } 1 \\
\text { (4 WAP) }\end{array}$ & $\begin{array}{l}\text { Stage } 2 \\
\text { (8WAP) }\end{array}$ & $\begin{array}{l}\text { Stage } 3 \\
\text { (12 WAP) }\end{array}$ & $\begin{array}{l}\text { Stage } 4 \\
\text { (16 WAP) }\end{array}$ & $\begin{array}{l}\text { Stage } 5 \\
\text { (20 WAP) }\end{array}$ & $\begin{array}{l}\text { Stage } 6 \\
\text { (24 WAP) }\end{array}$ \\
\hline Peel color & green & green & green & green & Light yellow & Yellowish orange \\
\hline $\begin{array}{l}\text { Pulp color and } \\
\text { nature }\end{array}$ & $\begin{array}{l}\text { White, hard, } \\
\text { gummy }\end{array}$ & $\begin{array}{l}\text { White, hard, } \\
\text { gummy }\end{array}$ & $\begin{array}{l}\text { Cream, hard, } \\
\text { gummy }\end{array}$ & $\begin{array}{l}\text { Yellow, hard, } \\
\text { gummy }\end{array}$ & $\begin{array}{l}\text { Yellow-orange, } \\
\text { hard, gummy }\end{array}$ & $\begin{array}{l}\text { Yellowish orange, } \\
\text { soft (edible) }\end{array}$ \\
\hline $\begin{array}{l}\text { Seed coat nature } \\
\text { and color }\end{array}$ & Not prominent & $\begin{array}{l}\text { Membraneous, } \\
\text { white }\end{array}$ & $\begin{array}{l}\text { Thick membrane, } \\
\text { white }\end{array}$ & $\begin{array}{l}\text { Hard, thick, } \\
\text { brown }\end{array}$ & Hard, thick, black & Hard thick, black \\
\hline Peel weight (g) & $0.23 \pm 0.02$ & $0.55 \pm 0.09$ & $1.34 \pm 0.082$ & $2.50 \pm 0.06$ & $3.43 \pm 0.32$ & $3.63 \pm 0.08$ \\
\hline Pulp weight(g) & $2.38 \pm 0.09$ & $4.85 \pm 0.05$ & $11.69 \pm 0.03$ & $33.65 \pm 1.2$ & $59.73 \pm 0.82$ & $64.79 \pm 2$ \\
\hline Seed weight(g) & $0.37 \pm 0.07$ & $0.220 \pm 0.01$ & $2.64 \pm 0.1$ & $5.56 \pm 0.07$ & $8.15 \pm 0.52$ & $9.13 \pm 0.5$ \\
\hline $\begin{array}{l}\text { Fruit circumference } \\
(\mathrm{cm})\end{array}$ & $5.8 \pm 0.04$ & $7.80 \pm 0.026$ & $12.05 \pm 0.5$ & $17.92 \pm 0.04$ & $21.05 \pm 0.76$ & $23.03 \pm 0.45$ \\
\hline
\end{tabular}

mean \pm SD $n=20 p<0.05$

\section{Total phenols and flavonoids}

The total phenolic and flavonoid contents of egg fruits at different developmental stages were measured by using a Folin-Ciocalteu assay and $\mathrm{NaNO}_{2}-\mathrm{Al}\left(\mathrm{NO}_{3}\right)_{3}-\mathrm{NaOH}$ test system.

As shown in the table (2), the total phenolic contents of egg fruits increased during development i.e., stage I to III and then declined i.e., at stage VI, total phenols was $2.26 \mathrm{mg} / \mathrm{g}$. Meanwhile, the flavonoids increased from stage (I) to stage (VI) from 0.683 and 3.37 $\mathrm{mg} / \mathrm{g}$ fresh weight (FW) in table 2 .

Many researchers have observed the decrease of total phenolic and/or flavonoid contents of other plant tissues during development. For example, variations in metabolites throughout plant development in Artemisia annua was reported [16]. Chemical changes and antioxidant activity in pomegranate arils during fruit development was also noticed [17]. Changes of antioxidative activity during florescence and flower senescence of Peonies petal were correlated [18]. Variations of polyphenols during fruit development in apples were also analyzed [19].

This may be due to the rapid growth of plant tissues in the early period, leading to a dilution effect of polyphenolic compounds. In the late period, the plant tissue grows slowly, while the oxidation and transformation of phenolic compounds may be accelerated due to the senescence of plant tissue.

A negative correlation between polyphenol content and peach blossoms during development was noted, which suggested that the increase in weight during the early periods may be one of the main reasons for the decline of phenolic content during fruit development [20]. Similarly, decline of some active components reported in the leaves of pigeon pea during vegetative growth has been attributed to the rapid growth of plant during that period [21].

Table 2: Estimation of total phenol content and flavonoids at different developmental stages of egg fruit

\begin{tabular}{lll}
\hline Stages & Total phenol (mg/g) & Flavonoid (mg/g) \\
\hline Stage 1(4WAP) & $30.35 \pm 0.3$ & $0.683 \pm 0.07$ \\
Stage 2(8WAP) & $41.59 \pm 0.4$ & $0.774 \pm 0.02$ \\
Stage 3(12WAP) & $46.59 \pm 0.3$ & $0.818 \pm 0.02$ \\
Stage 4(16WAP) & $26.46 \pm 0.2$ & $1.26 \pm 0.02$ \\
Stage 5(20WAP) & $17.52 \pm 0.3$ & $2.6 \pm 0.02$ \\
Stage 6 (24WAP) & $2.26 \pm 0.08$ & $3.37 \pm 0.03$ \\
\hline
\end{tabular}

mean \pm SD $n=20, p<0.05$ 


\section{Estimation of antioxidant potentiality (AOX)}

\section{Superoxide anion radical $\left(\mathrm{O}_{2} \cdot\right)$ scavenging capacity}

The superoxide anion radical $\left(\mathrm{O}_{2} \cdot-\right)$ scavenging capacities of aqueous and ethanolic fruit extracts from Pouteria campechiana were evaluated. As shown in table 3, the fruits of $P$. campechiana exhibited remarkable scavenging capacities towards superoxide anion radicals in ethanolic extract than aqueous. The superoxide anion radical scavenging capacity showed an ascending pattern with an increase of $71.9 \%(700 \mu \mathrm{g} / \mathrm{ml})$ for ethanolic antioxidant capacity and $60 \%$ for aqueous extract antioxidant capacity $(1000$ $\mu \mathrm{g} / \mathrm{ml})$. The difference in value indicated that the content of antioxidant components in different solvent extracts greatly vary depending on their polarity.

Table 3: Superoxide radical scavenging assay of stage VI fruit (24WAP)

\begin{tabular}{|c|c|c|c|}
\hline \multirow{2}{*}{$\begin{array}{l}\text { Concentration } \\
(\mu \mathrm{g} / \mathrm{ml})\end{array}$} & \% inhibition & \multirow{2}{*}{$\begin{array}{l}\text { Concentration } \\
(\mu \mathrm{g} / \mathrm{ml})\end{array}$} & \multirow{2}{*}{$\begin{array}{l}\% \text { inhibition } \\
\text { Aqueous extract (\%) }\end{array}$} \\
\hline & Ethanol extract (\%) & & \\
\hline 100 & $19.2 \pm 1.0$ & & \\
\hline 200 & 25. $3 \pm 0.82$ & 200 & $12.5 \pm 0.08$ \\
\hline 300 & $32 \pm 0.71$ & 400 & $21.3 \pm 0.14$ \\
\hline 400 & $42.03 \pm 0.16$ & 600 & $28.03 \pm 0.1$ \\
\hline 600 & $60.1 \pm 0.42$ & 800 & $49.08 \pm 0.35$ \\
\hline 700 & $71.9 \pm 0.31$ & 1000 & $60.01 \pm 0.1$ \\
\hline
\end{tabular}

The number of experiment $n=20$. The data were given in mena \pm SD.

There were variations in antioxidant potentiality among baobab, kiwi, orange, bilberry, and strawberry i.e., 1.2-386 (depending on the plant part), $0.73,17.0,1.95$, and $1.72 \mu \mathrm{mol}$ ascorbate/g respectively [22]. So the present antioxidant potential of egg fruits was more significant and may play an important role in preventing human health from oxidative stress. It has been reported that, the increasing order in the superoxide anion scavenging activity was due to the presence of hydroxyl group of phenolics.

\section{Hydroxyl radicals $(\mathrm{OH})$ scavenging power}

Hydroxyl radical $(\mathrm{OH})$ scavenging effects showed a dose-dependent pattern for ethanolic extracts. Moderate inhibition of. $\mathrm{OH}$ radicals against concentrations was displayed by alcoholic extract i.e., in ethanolic extract the inhibition ranged from 8.9 to $56 \%$ with 100 to $1000 \mu \mathrm{g} / \mathrm{ml}$ concentrations while no results were noticed with aqueous extract in table 4 .

Table 4: Hydroxyl radical scavenging assay of ethanolic extract of 24 WAP fruits

\begin{tabular}{ll}
\hline $\begin{array}{l}\text { Concentration } \\
(\boldsymbol{\mu g} / \mathbf{g})\end{array}$ & \% inhibition \\
\cline { 2 - 2 } 200 & Ethanol extract (\%) \\
400 & $8.9 \pm 0.02$ \\
600 & $15.4 \pm 0.11$ \\
800 & $20.81 \pm 0.1$ \\
1000 & $45.8 \pm 0.17$ \\
\hline
\end{tabular}

The number of experiments $n=20$. The data were given in mean \pm SD.

\section{Scavenging capacity of DPPH radicals}

Significant DPPH (1, 1-diphenyl-2-picrylhydrazyl) radical scavenging capacities were noticed with ethanolic and aqueous extracts and the results were superior to synthetic antioxidants such as quercetin and ascorbate (table 5). At concentration of $700 \mu \mathrm{g} / \mathrm{ml}$, the scavenging percentage was higher by $94.01 \%$, while it was only $64.6 \%$ at concentration of $1400 \mu \mathrm{g} / \mathrm{ml}$. Moreover, the DPPH radical scavenging effects also showed a dose-dependent pattern and increased with concentrations. As compared with hydroxyl radical assay, the scavenging capacity towards DPPH radicals was higher. The antioxidant capacity of pomegranate flower petal was determined and

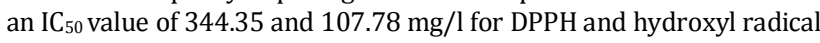
assay was obtained respectively, indicating that the flower petal extract could scavenge hydroxyl radical more efficiently [23]. This difference may be ascribed to the difference of composition of phytochemicals in the test samples, and thereby the reaction process as well as the mechanism involved may also differ from each other.

Table 5: DPPH scavenging assay using ethanol and water extract of fully ripened fruit

\begin{tabular}{|c|c|c|c|}
\hline \multirow{2}{*}{$\begin{array}{l}\text { Concentration } \\
(\mu \mathrm{g} / \mathrm{ml})\end{array}$} & \multirow{2}{*}{$\begin{array}{l}\% \text { of inhibition } \\
\text { Ethanol extract (\%) }\end{array}$} & \multirow{2}{*}{$\begin{array}{l}\text { Concentration } \\
(\mu \mathrm{g} / \mathrm{ml})\end{array}$} & \multirow{2}{*}{$\begin{array}{l}\% \text { of inhibition } \\
\text { Aqueous extract (\%) }\end{array}$} \\
\hline & & & \\
\hline 100 & $23.3 \pm 0.1$ & 200 & $21.31 \pm 0.12$ \\
\hline 200 & $44.0 \pm 0.17$ & 400 & $37.63 \pm 0.2$ \\
\hline 300 & $60.5 \pm 0.2$ & 600 & $52.63 \pm 0.16$ \\
\hline 400 & $71.5 \pm 0.31$ & 800 & $59.09 \pm 0.2$ \\
\hline 500 & $80 \pm 0.14$ & 1000 & $64.8 \pm 0.1$ \\
\hline 600 & $87.0 \pm 0.12$ & 1200 & $64.7 \pm 0.1$ \\
\hline 700 & $94.01 \pm 0.24$ & 1400 & $64.6 \pm 0.26$ \\
\hline
\end{tabular}

The number of experiments $n=20$. The data were given in mean \pm SD.

\section{FRAP assay}

Table 6 showed the FRAP of ethanolic and aqueous extracts of egg fruits. Ethanolic extract significantly affected $(p<0.05)$ the
FRAP content at different concentrations, the highest values were recorded in $400 \mu \mathrm{g} / \mathrm{ml}\left(81.5 \mathrm{mmol} \mathrm{Fe}{ }^{2+} / \mathrm{g}\right)$ and the lowest

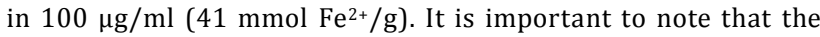
entire antioxidant capacity of the sample was derived by 
measuring their capacity to reduce $\mathrm{Fe}^{3+}$ to $\mathrm{Fe}^{2+}$ using FRAP test. The differences in the results obtained from different tropical fruits may be due to the increase in FRAP ability because of hydroxyls present in their lead molecules $(106 \pm 28 \mathrm{mg}$ TE/100g FW in papaya [24], 26-1393 $\mathrm{mg} \mathrm{TE} / 100 \mathrm{~g} \mathrm{FW}$ in banana [25], 160-180 $\mathrm{mg}$ TE/100 g FW in mango [24]). Analysis of antioxidant activity in different fractions of tomatoes has been conducted [26]. In mango fruit, the fibre content was associated with antioxidant capacity that points its importance as bakery product ingredient [26]. Analysis of the activity and contents of polyphenolic antioxidants in the whole fruit, flesh and peel of three apple cultivars was performed [27].

Table 6: FRAP assay of ethanolic and water extract from fruit (24WAP)

\begin{tabular}{|c|c|c|c|}
\hline \multirow{2}{*}{$\begin{array}{l}\text { Concentration } \\
(\mu \mathrm{g} / \mathrm{ml})\end{array}$} & \multirow{2}{*}{$\begin{array}{l}\text { Ferric reducing ability } \\
\left.\text { Ethanol extract (mmol Fe }{ }^{2+} / \mathrm{g}\right)\end{array}$} & \multirow{2}{*}{$\begin{array}{l}\text { Concentration } \\
(\mu \mathrm{g} / \mathrm{ml})\end{array}$} & \multirow{2}{*}{$\begin{array}{l}\text { Ferric reducing ability } \\
\text { Aqueous extract }\left(\mathrm{mmol} \mathrm{Fe}^{2+} / \mathrm{g}\right)\end{array}$} \\
\hline & & & \\
\hline 100 & $41 \pm 0.1$ & 500 & $30.1 \pm 0.18$ \\
\hline 150 & $56 \pm 0.11$ & 750 & $38.9 \pm 0.31$ \\
\hline 200 & $63 \pm 0.21$ & 1000 & $44.5 \pm 0.26$ \\
\hline 250 & $71 \pm 0.3$ & 1250 & $49.0 \pm 0.42$ \\
\hline 300 & $79 \pm 0.21$ & 1500 & $57.3 \pm 0.2$ \\
\hline 350 & $80 \pm 0.2$ & 1750 & $62.01 \pm 0.1$ \\
\hline 400 & $81.5 \pm 0.7$ & 2000 & $62.0 \pm 0.1 .3$ \\
\hline
\end{tabular}

The number of experimentsn=20. The data were given in mean \pm SD.

\section{Hydrogen peroxide $\left(\mathrm{H}_{2} \mathrm{O}_{2}\right)$ radical scavenging activity}

The scavenging effect of different solvent extracts of fruit on hydrogen peroxide $\left(\mathrm{H}_{2} \mathrm{O}_{2}\right)$ was concentration-dependent (10-800 $\mu \mathrm{g} / \mathrm{ml}$ ) as shown in table 7. Ethanolic extract displayed strong $\mathrm{H}_{2} \mathrm{O}_{2}$ scavenging activity (31.3 to $68 \%$ with 10 to $70 \mu \mathrm{g} / \mathrm{ml}$ ) whereas that of the standard, ascorbic acid exhibited $89 \%$ of inhibition at $50 \mu \mathrm{g} / \mathrm{ml}$. The scavenging activity of aqueous extract was less (24.6 to $65.94 \%$ with 200 to $800 \mu \mathrm{g} / \mathrm{ml}$ ) in table (7). $\mathrm{EC}_{50}$ values of the fractions in scavenging hydrogen peroxide were significantly different $(p<0.05)$ from the $\mathrm{EC}_{50}$ values obtained for ascorbic acid.

Table 7: Hydrogen peroxide scavenging assay of ethanolic and aqueous extract (24WAP)

\begin{tabular}{llll}
\hline $\begin{array}{l}\text { Concentration } \\
(\boldsymbol{\mu g} / \mathbf{m l})\end{array}$ & \begin{tabular}{l} 
\% inhibition \\
\cline { 2 - 3 }
\end{tabular} & $\begin{array}{l}\text { Concentration } \\
(\boldsymbol{\mu g} / \mathbf{m l})\end{array}$ & $\begin{array}{l}\text { \% inhibition } \\
\text { Aqueous extract }(\%)\end{array}$ \\
\hline 10 & $31.3 \pm 0.1$ & 200 & $24.6 \pm 0.39$ \\
20 & $44.7 \pm 0.22$ & 300 & $29 \pm 0.65$ \\
30 & $49.0 \pm 0.23$ & 400 & $33.1 \pm 0.1$ \\
40 & $56.9 \pm 0.17$ & 500 & $39.1 \pm 0.41$ \\
50 & $62.1 \pm 0.3$ & 600 & $53.0 \pm 0.33$ \\
60 & $68.01 \pm 0.19$ & 700 & $62.51 \pm 0.08$ \\
70 & $68 \pm 0.1$ & 800 & $65.94 \pm 0.06$ \\
\hline
\end{tabular}

The number of experiments $n=20$. The data were given in $\pm S D$.

\section{ABTS radical scavenging activity}

Both the extracts scavenged ABTS radical in a concentration-dependent way $(100-500 \mu \mathrm{g} / \mathrm{ml}$ alcoholic while in aqueous $100-1000 \mu \mathrm{g} / \mathrm{ml}$ ) in table 8. Present results showed that the ABTS radical scavenging ability of samples can be ranked as ethanolic followed by aqueous.

\section{Metal chelating activity}

Table 9 shows the dose response curves for metal chelating power of ethanolic and aqueous extract (100-170 $\mu \mathrm{g} / \mathrm{ml})$. Most ROSs were generated as by-products during mitochondrial electron transport and other metabolic reactions.

Table 8: ABTS scavenging assay of ethanolic and water extract from fruit (24WAP)

\begin{tabular}{|c|c|c|c|}
\hline \multirow{2}{*}{$\begin{array}{l}\text { Concentration } \\
(\mu \mathrm{g} / \mathrm{ml})\end{array}$} & \% inhibition & \multirow{2}{*}{$\begin{array}{l}\text { Concentration } \\
(\mu \mathrm{g} / \mathrm{ml})\end{array}$} & \multirow{2}{*}{$\begin{array}{l}\% \text { of inhibition } \\
\text { Aqueous extract (\%) }\end{array}$} \\
\hline & Ethanol extract (\%) & & \\
\hline 100 & $23.02 \pm 0.19$ & 200 & $21.2 \pm 0.11$ \\
\hline 150 & $32.55 \pm 0.13$ & 300 & $29.03 \pm 0.16$ \\
\hline 200 & $45.05 \pm 0.1$ & 400 & $34.7 \pm 0.16$ \\
\hline 250 & $53.0 \pm 0.23$ & 500 & $41.24 \pm 0.1$ \\
\hline 300 & $60.39 \pm 0.2$ & 600 & $56.02 \pm 0.3$ \\
\hline 350 & $69.71 \pm 0.25$ & 700 & $61.01 \pm 0.13$ \\
\hline 400 & $69.41 \pm 0.2$ & 800 & $61.39 \pm 0.2$ \\
\hline 450 & $69.3 \pm 0.15$ & 900 & $61.30 \pm 0.18$ \\
\hline 500 & $69.2 \pm 0.19$ & 1000 & $61.3 \pm 3.3$ \\
\hline
\end{tabular}

The number of experiments $n=20$. The data were given in mean \pm SD.

In addition, ROS were formed as necessary intermediates of metal catalyzed oxidation reactions. The transition metal ion $\mathrm{Fe}^{2+}$ possessed the ability to perpetuate the formation of free radicals by gain or loss of electrons. Therefore, the reduction of the formation of reactive oxygen species can be achieved by the chelation of metal ions with chelating agents. Chelation power assay 
was carried out to assess the chelation capacity of the crude extracts which illustrated that both the crude aqueous and ethanolic extracts possessed remarkable chelation power from 100 to $170 \mu \mathrm{g} / \mathrm{ml}(73.6$ and $68.4 \%$ respectively). Excess of metal ions could lead to various anomalies in the body. The iron (II) chelating activity of plant extracts is of great significance, because it has been proposed that the transition metal ions contribute to the oxidative damage in neurodegenerative disorders like
Alzheimer's and Parkinson's diseases. Also, chelation therapy is a common practice of neutralising iron overload in the body especially in cases of treatment of Thalassemia and other anemias. The current scenario suggests that the chelation therapy makes use of synthetic compounds which have certain side effects as well $[29,30]$. Therefore, chelation of metal ions by natural phytochemicals from egg fruits can prove to be of therapeutic importance.

Table: 9 Metal chelating activity of ethanolic and aqueous extract from fully ripened fruit

\begin{tabular}{llll}
\hline $\begin{array}{l}\text { Concentration } \\
(\boldsymbol{\mu g} / \mathbf{m l})\end{array}$ & \begin{tabular}{l} 
\% inhibition \\
\cline { 2 - 3 }
\end{tabular} & $\begin{array}{l}\text { Concentration } \\
(\boldsymbol{\mu g} / \mathbf{m l})\end{array}$ & $\begin{array}{l}\text { \% inhibition } \\
\text { Ethanol extract (\%) }\end{array}$ \\
\hline 100 & $23.33 \pm 0.17$ & 100 & $43.02 \pm 0.13$ \\
110 & $31.0 \pm 0.1$ & 110 & $51.7 \pm 0.1$ \\
120 & $40.11 \pm 0.24$ & 120 & $59.0 \pm 0.2$ \\
130 & $52.0 \pm 0.29$ & 130 & $65.11 \pm 0.2$ \\
140 & $57.6 \pm 0.3$ & 140 & $70.01 \pm 0.31$ \\
150 & $63.2 \pm 0.4$ & 150 & $73.33 \pm 0.22$ \\
160 & $68.1 \pm 0.001$ & 160 & $73.30 \pm 0.01$ \\
170 & $68.4 \pm 0.21$ & 170 & $73.6 \pm 0.24$ \\
\hline
\end{tabular}

The number of experiments $n=20$. The data were given in mean \pm SD.

Mechanism of flavonoids as antioxidants for protecting the body against reactive oxygen species may be via the additive effect to the endogenous scavenging compounds. Flavonoids can interfere with $\geq 3$ different free radical-producing systems, which are described below, but they can also increase the function of the endogenous antioxidants. Flavonoids can prevent injury caused by free radicals in various ways. One way is the direct scavenging of free radicals. Flavonoids are oxidized by radicals, resulting in a more stable, less-reactive radical. In other words, flavonoids stabilize the reactive oxygen species by reacting with the reactive compound of the radical. Because of the high reactivity of the hydroxyl group of the flavonoids, radicals are made inactive, according to the following equation [31].

Flavonoid $(\mathrm{OH})+\mathrm{R} \cdot>$ Flavonoid $(\mathrm{O} \cdot)+\mathrm{RH}$

Where $\mathrm{R} \cdot$ is a free radical and $\mathrm{O} \cdot$ is an oxygen free radical. Selected flavonoids can directly scavenge superoxides, whereas other flavonoids can scavenge the highly reactive oxygen-derived radical called peroxynitrite. Epicatechin and rutin are also powerful radical scavengers. The scavenging ability of rutin may be due to its inhibitory activity on the enzyme xanthine oxidase. By scavenging radicals, flavonoids can inhibit LDL oxidation in vitro. This action protects the LDL particles and, theoretically, flavonoids may have preventive action against atherosclerosis.

The antioxidant compounds and total antioxidant activity in fruits of acerola Cv. Flor Branca, Florida Sweet and Brs 3661were assessed [32]. In apples, antioxidant activity at different maturity stages and fruit parts was compared [33]. Correlation of total phenolics, flavonoid content and antioxidant profile of different date varieties were also done [34]. In Eugenia jambolana, fruit maturity, phenolic content and antioxidant activity were evaluated [35]. Metal ion chelating activity and hydrogen peroxide scavenging activity of Kalanchoe pinnata were analyzed [36]. In tomato fruits, the evolution of antioxidant activity and bioactive compounds during growth and ripening was also reported [37]. The fruit of Phyllanthus emblica showed antioxidant property due to certain phytochemical compounds such as tannins, flavonoids, terpinoids and alkaloids [38]. The extract of Myxopyrum smilacifolium showed higher antioxidant property than control but less than ascorbic acid [39]. All these support the present antioxidant power of egg fruits.

\section{CONCLUSION}

The assessment of the chemical composition and antioxidant activity of egg fruits may allow increased utilization of the fruit as a functional food. In this study, total phenols, flavonoids and antioxidant activity were commendable, compared with other common fruits. Total phenol and flavonoids of egg fruit examined in this study was comparable with that of cranberry, red grape or strawberry, peach, apple, orange, banana, pear, pineapple, some blueberry cultivars and grapefruit. Correlations between polyphenols and antioxidant activity suggested that phytochemical components of egg fruit have an important effect on antioxidant capacity, as reported for other fruits and vegetables. The bioactivities of the underutilized species points to a new source of natural health promoting compounds.

\section{AUTHORS CONTRIBUTION}

Both Sunila and Murugan contributed in the analysis of variation shown by the phytochemical constituents along with antioxidant activity related to the fruits of Pouteria campechiana at different stages.

\section{CONFLICT OF INTERESTS}

Declared none

\section{REFERENCES}

1. Nakamura YS, Watanabe N, Kohno MH, Osawa T. Dihydrochalcones: evaluation as novel radical scavenging antioxidants. J Agric Food Chem 2003;51:3309-12.

2. Imeh U, Khokhar S. Distribution of conjugated and free phenols in fruits: antioxidant activity and cultivar variations. J Agric Food Chem 2002;50:6301-6.

3. Alesiani D, Canini A, D'Abrosca B, DellaGreca M, Fiorentino A, Mastellone $\mathrm{C}$, et al. Antioxidant and antiproliferative activities of phytochemicals from Quince (Cydonia vulgaris) peels. Food Chem 2010;118:199-207.

4. Gil MI, Tomas-Barberan F, Hess-Pierce B, Holcroft D, Kder A. Antioxidant activity of pomegranate juice and its relationship with phenolic composition and processing. J Agric Food Chem 2000;48:4581-9.

5. Williams GM, Jeffrey AM. Oxidative DNA damage: endogenous and chemically induced. Regul Toxicol Pharmacol 2000;32:283-92.

6. Halliwell B. Establishing the significance and optimal intake of dietaryantioxidants: the biomarker concept. Nutr Rev 1999;57:104-13.

7. Mayer V, Treeter D, Santo Buelga C, Bauer H, Feucht W. Developmental changes in the phenol concentration of golden delicious apple fruits and leaves. Phytochem 1995;38:1151-5.

8. Chang CC, Yan MH, Wen HM, Chern JC. Estimation of total flavonoid content in propolis by two complementary colorimetric methods. J Food Drug Anal 2002;10:178-82.

9. Jing TY, Zhao XY. The improved pyrogallol method by using termination agent for superoxide dismutase measurement. Prog Biochem Biophys 1995;22:84-6.

10. Martin S, Kavitha PD, Rakhi MA, Kumar DG, Gopalakrishnan VK. Cytotoxic activity of Pergularia daemia against ovarian cancer cell lines OAW-42 and PA-1. J Nat Phram 2011;2:203-9. 
11. Rajesh PM, Natvar PJ. In vitro antioxidant activity of coumarin compounds by DPPH, Super oxide and nitric oxide free radical scavenging methods. J Adv Pharm Edu Res 2011;1:52-68.

12. Jayalakshmia S, Mishraa A, Mishraa A, Singlab RK, Ghosha AK. In vitro evaluation of antioxidant activity of five drugs of Trinpanchmool. Pharmacol 2011;2:1153-9.

13. Keser S, Celik S, Turkoglu S, Yilmaz O, Turkoglu I. Hydrogen peroxide radical scavenging and total antioxidant activity of Hawthorn. Chem J 2012;2:9-12.

14. Re R, Pellegrini N, Proteggente A, Pannala A, Yang M, RiceEvans C. Antioxidant activity applying an improved ABTS radical cation decolorization assay. Free Radical Biol Med 1999;26:1231-7.

15. Rajic Z, Koncic ZM, Miloloza K, Perkovic I, Butula I, Bucar F, et al. Primaquine-NSAID twin drugs: synthesis, radical scavenging, antioxidant and Fe2+chelating activity. Acta Pharm 2010;60:325-37.

16. Towler MJ, Weathers PJ. Variations in key artemisinic and other metabolites throughout plant development in Artemisia annua L. for potential therapeutic use. Ind Crops Prod 2015;67:185-91.

17. Kulkarni AP, Aradhya SM. Chemical changes and antioxidant activity in pomegranate arils during fruit development. Food Chem 2005;93:319-24.

18. Shi GA, Guo XF, Fan BY, Bao MZ. Changes of antioxidative activity duringflorescence and flower senesce nce of peonies petal. Acta Hort Sin 2009;36:1685-90.

19. Wang SX, Liu JC, Jiao ZG, Zhang SN, Yang L. Changes of polyphenols during fruit development in apples. J Fruit Sci 2003;20:427-31.

20. Liu J, Jiao Z, Yang W, Zhang C, Liu H, Lv Z. Variation in phenolics, flavanoids, antioxidant and tyrosinase inhibitory activity of peach blossoms at different developmental stages. Molecules 2015;20:20460-72.

21. Wei ZF, Jin S, Luo M, Pan YZ, Li TT, Qi XL, et al. Variation in contents of main active components and antioxidant activity in leaves of different pigeon pea cultivars during growth. J Agric Food Chem 2013;61:10002-9.

22. Besco E, Braccioli E, Vertuan S, Ziosi P, Brazzo F, Bruni R, et al. The use of photochemiluminescence for the measurement of the integral antioxidant capacity of baobab products. Food Chem 2007;102:1352-6.

23. Zhang L, Yang X, Zhang Y, Wang L, Zhang R. In vitro antioxidant properties of different parts of pomegranate flowe rs. Food Bioprod Process 2011;89:234-40.

24. Lim YY, Lim TT, Tee JJ. Antioxidant properties of several tropical fruits: a comparative study. Food Chem 2007;103:1003-8.

25. Sulaiman SF, Yusoff NA, Eldeen IM, Seow EM, Sajak AA, Supriatno, et al. Correlation between total phenolic and mineral contents with antioxidant activity of eight Malaysian bananas (Musa sp.). J Food Comp Anal 2011;24:1-10.

26. Toor RK, Savage GP. Antioxidant activity in different fractions of tomatoes. Food Res Int Toronto 2005;38:487-94.

27. Vergara-Valencia N, Granados-Pérez E, Agama-Acevedo E, Tovar J, Ruales J, Bello-Pérez LA. Fibre concentrate from mango fruit: characterization, associated antioxidant capacity and application as a bakery product ingredient. LWT-Food Sci Techol Amsterdam 2007;40:722-9.

28. Vieira FGK, Borges GSC, Copetti C, Gonzaga LV, Nunes EC, Fett R. Activity and contents of polyphenolic antioxidants in the whole fruit, flesh and peel of three apple cultivars. Arch Latinoam Nutr Caracas 2009;59:101-6.

29. Komes D, Belscak-Cvitanovic A, Horzic D, Rusak G, Likic S, Berendika M. Phenolic composition and antioxidant properties of some traditionally used medicinal plants affected by the extraction time and hydrolysis. Phytochem Anal 2011;22:172-80.

30. Faller ALK, Fialho E. Polyphenol content and antioxidant capacity in organic and conventional plant foods. J Food Comp Anal 2010;23:561-8.

31. Nijveldt J, Nood Ev, Van Hoorn DEC, Boelens PG, K Van Norren K, Van Leeuw PAM. Flavonoids: a review of probable mechanisms of action and potential applications. Am J Clin Nutr 2001;74:418-25.

32. De Souza KO, Moura CFH, De Brito ES, De Mir MRA. Antioxidant compounds and total antioxidant activity in fruits of Acerola from Cv. Flor Branca, Florida Sweet Brs 3661 Rev Bras Frutic Jaboticabal 2014;36:294-304.

33. Duda-Chodak A, Tarko T, Tuszyński T. Antioxidant activity of apples-an impact of maturity stage and fruit part. Acta Sci Pol Technol Aliment 2011;10:443-54.

34. Singh V, Guizani N, Essa MM, Hakkim FL, Rahman MS. Comparative analysis of total phenolics, flavonoid content and antioxidant profile of different date varieties (Phoenix dactylifera L.) from sultanate of Oman. Int Food Res J 2012;19:1063-70.

35. Balamurugan S. Fruit maturity phenolic content and antioxidant activity of Eugenia jambolana lam fruit. Int Lett Nat Sci 2014;8:41-4.

36. Chandra Mohan S, Balamurugan V, Thiripura Salini S, Rekha R. Metal ion chelating activity and hydrogen peroxide scavenging activity of medicinal plant Kalanchoe pinnata. J Chem Pharm Res 2012; 4:197-202.

37. Nour V, Trandafir I, Ionica ME. Evolution of antioxidant activity and bioactive compounds in tomato (Lycopersicon esculentum Mill.) fruits during growth and ripening. J Appl Bot Food Qual 2014;87:97-103.

38. Krishnaveni M, Mirunalini S. Amla-The role of ayurvedic therapeutic herb in cancer. Asian J Pharm Clin Res 2011;4:13-7.

39. Siju EN, JollySamu, Minil M, Rajalakshmi GR. Antioxidant activity of Myxopyrum smilacifolium Blume. Asian J Pharm Clin Res 2015;3:2278-4357. 